\title{
The bio-mechanical properties of coco wood applied with Neem extracts: a potential preservative for sustainable building in Marinduque, Philippines
}

\author{
Froilan P. Ney ${ }^{1 *}$ (D, Dannielle Claudette L. Malco ${ }^{1}$, Delia B. Senoro ${ }^{2}$ and Merian Catajay-Mani ${ }^{3}$
}

\begin{abstract}
The purpose of this study was to develop an organic wood preservative from the liquid extract of Neem tree (Azadirachta indica). This product has the potential in controlling the fast deterioration of coco wood by extracting liquid from fruits with seeds and leaves of Neem tree. Effectiveness as wood preservative was investigated for termite repellency, water absorption, and tangential swelling following American Society for Testing and Materials methods such as D-3345-74, D-4442-92, and D-4446-06, respectively. The study revealed that wood samples with Neem extracts have favorable effects in preserving coco wood. It was also observed that extract from Neem leaves and fruits with seeds has no significant difference in terms of effectiveness on wood preservation displayed and coco wood physical characterization. The majority of the results were commensurate to gear on an affirmative finding to conclude that the liquid extract from Neem can be used and further explored as an effective material for wood preservation.
\end{abstract}

Keywords: Coco wood, Neem extract, Preservative, Philippines, Resource utilization

\section{Introduction}

Wood has been used by the Filipinos for thousands of years for both fuel (cooking), heating, and construction materials for primary (trusses, girders, beams, columns) and secondary (joists, studs) elements of houses. It is composed of cellulose fibers that possess good mechanical properties. Support material such as door and window frames/jambs, building forms in which concrete is poured during reinforced concrete construction, and other part of house structures is usually made up of woods. In the Philippines, coco wood is normally used as concrete forms and scaffoldings of small to medium category builders, instead of steel pipes and plates. In rural areas where there is limited access to cement and other concrete aggregates, coconut lumber is used as alternative structural members for houses. Philippines is among the world's top producer of coconuts having a total plantation area of about 3.52 million ha in 68 provinces as of the year 2015 [1]. A

\footnotetext{
* Correspondence: fpney@yahoo.com

${ }^{1}$ Department of Civil Engineering, Marinduque State College, 4900 Boac, Philippines

Full list of author information is available at the end of the article
}

significant volume of coconut lumber was used in the lowcost housing program, as well as in others and various resorts throughout the country. This involves some 1 to 2 million $\mathrm{m}^{3}$ of coconut lumber annually [2]. Marinduque, a small island in the Southern Tagalog Region of Luzon, considers coconut as their primary crop with $66 \%$ of their crop land areas devoted to coconut plantation. The outer, higher density stem fibers of coco lumber or coco wood have properties similar to many hardwood timbers and possibly may have high value flooring product [3]. However, in countries with tropical climate with high relative humidity, the service life of coco wood is reduced due to various environmental conditions such as precipitation and increased ambient temperature favorable to biological degradation. This coco wood and other types of wood become susceptible to biodegradation when exposed to these environmental factors. Wood is a hydroscopic material that possesses water absorption properties reducing its physico-mechanical properties. Periodic exposure of untreated wood to precipitation increases its moisture content and adversely affects the quality of wood. 


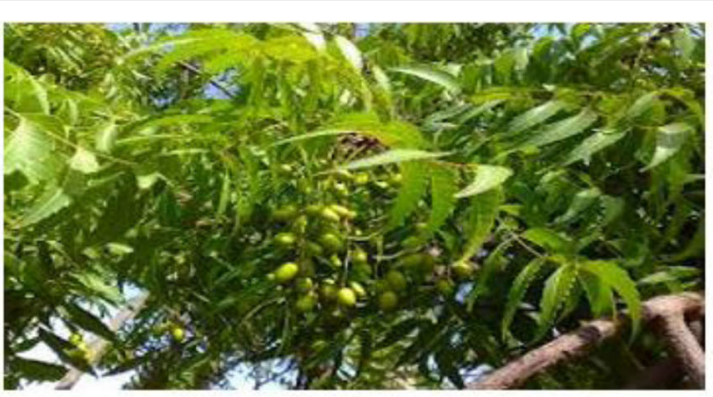

(a)

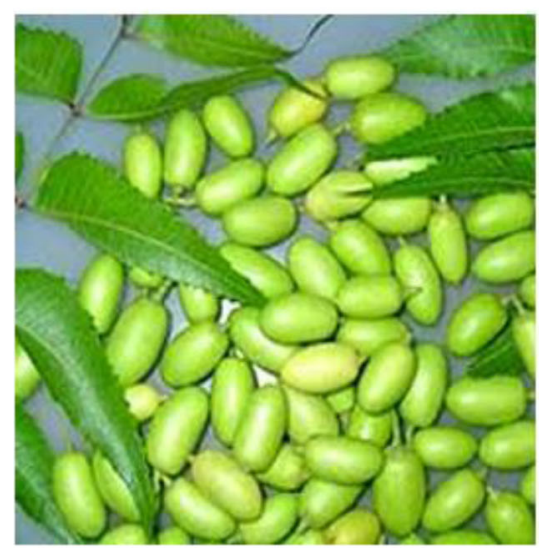

(b)

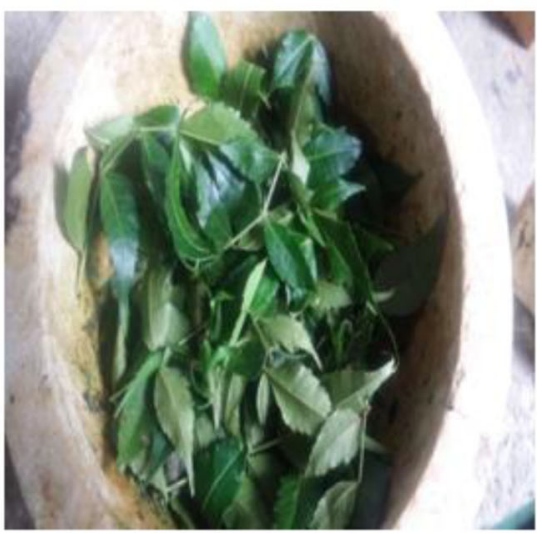

(c)

Fig. 1 Neem tree (a) showing its fruits (b) and leaves (c)

Wood with high moisture content is vulnerable to microbiological (especially fungi) and insect attack which causes wood dimensional instability especially under varying moisture conditions $[4,5]$. Woody tissues are degraded by fungi through the cell [6]. The ability of microorganisms to attack wood depends on the moisture content of the wood cell wall and the reactivity of its chemical components [7, 8]. Biodegradation is dependent upon many factors including moisture content above 30\% [9] temperature, microbial population, degree of acclimatization, accessibility of nutrient, cellular transport properties and chemical portioning of growth medium [10]. Another prevalent wood threat is the white ants or termites (Termitoidae). These group of insects were classified at the taxonomic rank of order Isoptera (termites).
In natural environment, they are useful in helping break down nutrients from dead plants to humus. However, these insects become threat to woods as these can do damage to unprotected buildings and their wooden elements. They can attack wood in a building from below the ground level up to the highest point of the roof. Over time, the moisture content in the woods plus the significant termite damage become a problem that requires immediate attention and solution. United States, Japan and Philippines reported billions of US dollars are spent annually for termite control and repairing the damages [11-15]. There are numerous ways to extend the service life of wood products and building materials that have been developed including chemical treatments and costly alternative materials. Pesticides such as

Table 1 Composition of Neem extracts from seeds, leaves, flowers

\begin{tabular}{|c|c|c|c|}
\hline Component & Part of Neem tree & Potential application & Source \\
\hline Limonoids & Not specific to any part of the tree & Biopesticides & [21] \\
\hline Azadirachitin & Seeds & Ability to repel pests such as locusts & [22] \\
\hline Proline & Leaf & Ability for skin ailment cure & [23] \\
\hline Lipids, proteins, parietal constituents & Seeds & Biofuel, and soaps & [24] \\
\hline $\begin{array}{l}\text { Terpenoids, pentcosane, octadecanol, } \\
\text { tetracosane, } \beta \text {-germacrene, } \beta \text { - } \\
\text { caryophyllene, verdiflorol }\end{array}$ & Flowers, leaves & Antioxidant, antibacterial, larvicidal deterrent & [25] \\
\hline
\end{tabular}




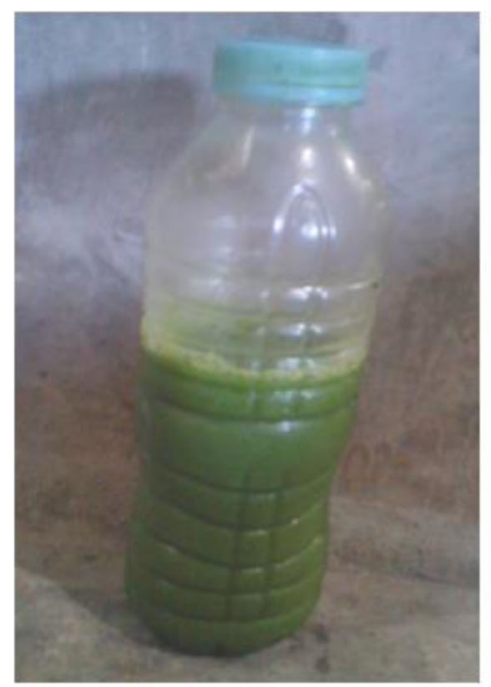

(a) Extract from leaves

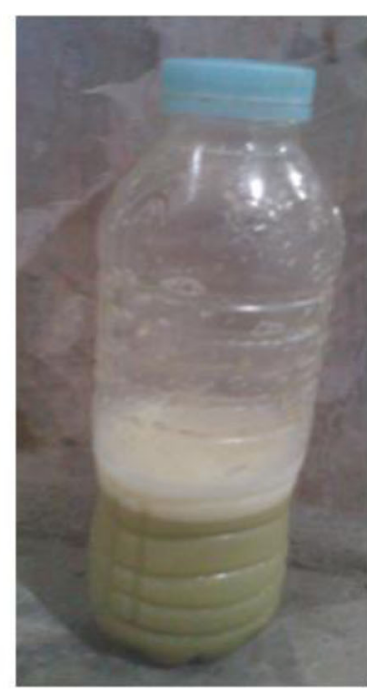

(b) Extract from fruits with seeds

Fig. 2 Extracts produced from crushing the fruits with seeds and leaves of Neem tree (a) The conceptual framework (b) The experimental set-up

chlordane and heptachlor, among others, are effective tool against termites. While wood preservatives that contain active ingredients like permethrin, propiconazole and tebuconazole are commercialized and now in the market. However, it has been proven that these preservatives contain chemicals that cause adverse effects on human health. For example, excessive human exposure to permethrin can cause nausea, headache, muscle weakness, excessive salivation, shortness of breath, and seizures [16] while propiconazole is a possible liver toxicant and may cause some issues in the endocrine system while tebuconazole is a possible human carcinogen [17]. Moreover, the high material cost of this commercial wood preservatives ranging from 21.4 to 27.8 USD per liter $[18,19]$ becomes the challenge to people to purchase the product. Thus, several new alternatives have been developed for termite control to reduce the potential for chemical exposure. This includes the production of pesticides from natural organic substances.

Neem or Nimtree (Azadirachta indica) (Fig. 1), on the other hand, is a tree belonging to the Mahogany family.

(a) The conceptual framework

\begin{tabular}{|c|c|c|}
\hline $\begin{array}{c}\text { INPUT } \\
\text { Neem extract } \\
\text { from fruits and } \\
\text { leaves } \\
\text { Wood samples }\end{array}$ & $\begin{array}{c}\text { PROCESS } \\
\text { Termite repellency test } \\
\text { Water absorbency test } \\
\text { Tangential swelling test }\end{array}$ & $\begin{array}{c}\text { OUTPUT } \\
\text { Effectiveness of Neem } \\
\text { extract from fruits and } \\
\text { leaves as wood } \\
\text { preservatives }\end{array}$ \\
\hline
\end{tabular}

(b) The experimental set-up

\begin{tabular}{|c|c|c|c|c|}
\hline $\begin{array}{c}\text { Controlled } \\
\text { (Pristine) sample }\end{array}$ & /I & $\begin{array}{l}\text { Treated sample (with } \\
\text { neem extracts from } \\
\text { fruit and leaves) }\end{array}$ & /I & $\begin{array}{l}\text { Termite exposure } \\
\text { Moisture exposure }\end{array}$ \\
\hline
\end{tabular}

Fig. 3 The study framework 


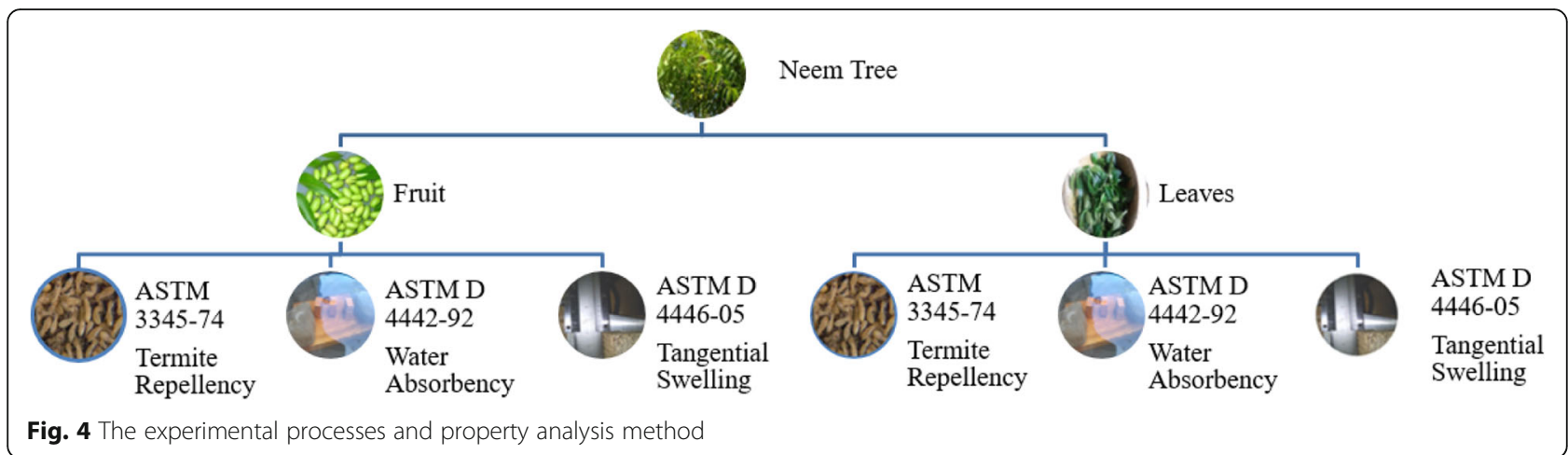

In the Philippines, same species is known as Philippine Nimtree, and commonly known in Tagalog as "Balunga" (local dialect). The Neem tree can reach a height of 15$20 \mathrm{~m}(49-66 \mathrm{ft})$, rarely to $35-40 \mathrm{~m}(115-131 \mathrm{ft})$. In 1978 , Neem was introduced to the Philippines by scientists working at the International Rice Research Institute (IRRI). By 1990, however, IRRI had distributed more than 120,000 seedlings and the tree was growing on at least eight islands [20]. It is popular in Marinduque for its insecticidal properties (especially mosquito repellency) and medicinal applications (dental antiseptic). Based on various studies (Table 1) Neem tree contains substances (e.g., azadirachitin, limonoid, proline) [21] known for wood preservation. Hence, this study utilized Neem fruits and leaves to develop an organic wood preservative that will help extend the service life of coco wood within Philippines environmental condition. This study paid special attention to the physical and chemicals parameters of coco wood in the presence of wood preservative such as termite repellency, water absorption and tangential swelling. Determining these parameters is helpful to extend the coco wood service life with lesser hazard, low cost with good quality and easy to produce. The result of this study is also helpful for the construction industry and local communities in Marinduque.

\section{Materials and methods}

The study utilized the simple extraction process with extracts produced shown in Fig. 2, as well as experimental framework (Fig. 3). Freshly harvested leaves and fruits were collected from a Neem tree, washed and rinsed to remove dusts and other impurities. The fruits with seeds were separated from leaves and cut into smaller pieces about $1-3 \mathrm{~cm}$ for easy crushing. The cut Neem fruits with seeds, and leaves were placed into the $1.5 \mathrm{~L}$ Microbishi fruit blender/ grinder separately, mixed with $120 \mathrm{~mL}$ of water, crushing/blending for about 2-3 min. Crushed Neem

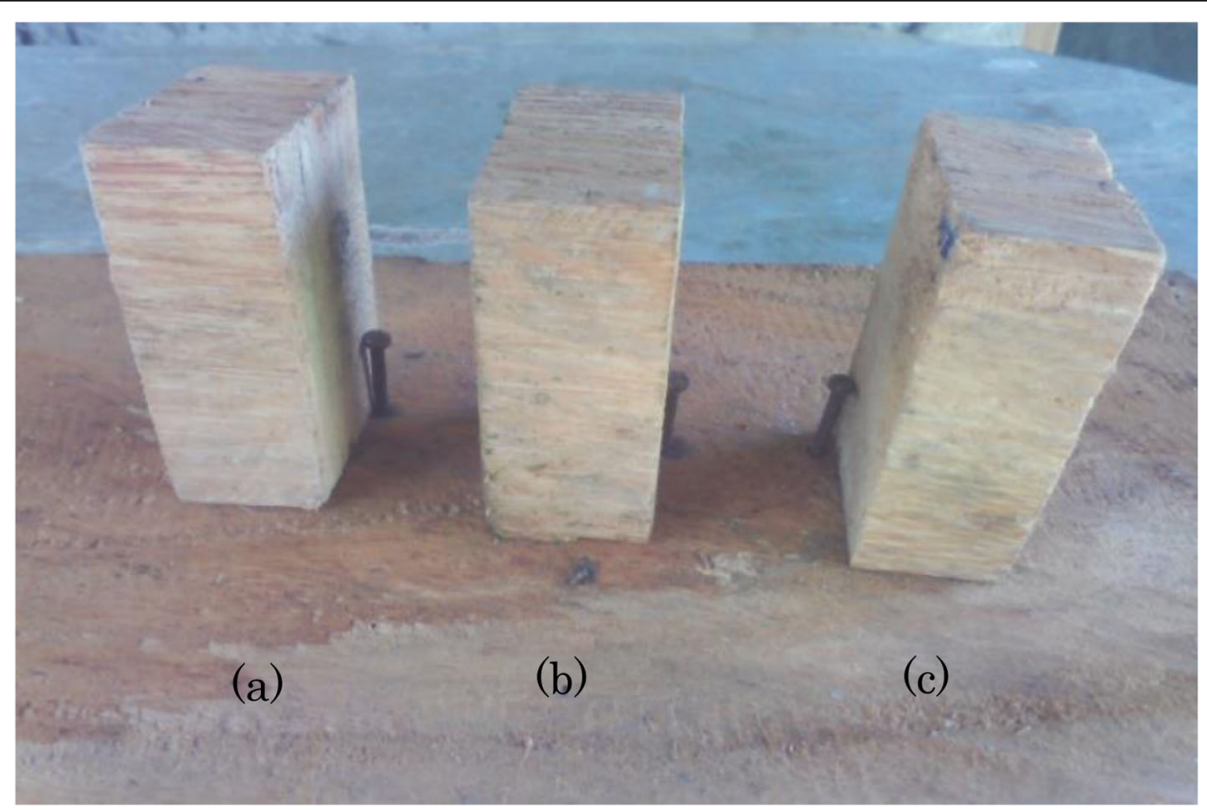

Fig. 5 Coco wood (lumber) samples and set-up with (a) controlled sample (b) sample with leaves extract and (c) sample with fruit extract 
Table 2 Data assessment and evaluation of coco wood property

\begin{tabular}{llll}
\hline $\begin{array}{l}\text { Test } \\
\text { Number }\end{array}$ & Coco lumber & Instrument used, & Data evaluation, \\
property & Data assessment & wt\% \\
\hline$(1)$ & Termite repellency & weighing scale and caliper & $\%(\mathrm{Wo}-\mathrm{Wn}) / \mathrm{Wo}$ \\
$(2)$ & Water absorbency & water, weighing scale, caliper & $\%=100(\mathrm{Wn}-\mathrm{Wo}) / \mathrm{Wo}$ \\
$(3)$ & Tangential swelling & weighing scale, caliper & $\%=100(\mathrm{Vn}-\mathrm{Vo}) / \mathrm{No}$ \\
\hline
\end{tabular}

Where;

$\mathrm{W}_{\mathrm{o}}$ = initial weight of wood sample

$W_{n}=$ the weight of wood sample after " $n$ " time

$V_{\mathrm{o}}=$ initial volume of the wood sample

$V_{n}=$ the volume of the wood sample after " $n$ " time

components were placed on a clean cloth, squeezing out the extracts (oil). Neem leaves and fruits oil were then placed in bottle (a) and (b), respectively (Fig. 2). The analytical methods of different properties for extracts are shown in Fig. 4.

The formulation by weight used was $66.67 \mathrm{~g}$ of fruits or leaves in $1 \mathrm{~L}$ of water. Three (3) coco wood sample set-up (Fig. 5) for each analysis with three samples for each set-up prepared. Sample [A] was the controlled and untreated sample. Samples $[B]$ and $[C]$ were the coco wood treated with extracts from leaves and fruit with seed, respectively. The sample size was $7.6 \times$ $5.1 \times 1.3 \mathrm{~cm}\left(50.4 \mathrm{~cm}^{3}\right)$ with weight range of $27-28 \mathrm{~g}$. Each type of sample was subjected to Test 1, 2, and 3 shown in Table 2 while Table 3 shows the corresponding ASTM method employed in the study. Table 2 also shows equations used during data evaluation. Weights and dimensions were measured using a digital weighing scale with $0.01 \mathrm{~g}$ division and a carbon steel Vernier caliper $150 \mathrm{~mm}$ range with $0.02 \mathrm{~mm}$ resolution. ASTM D-3345-74 (Standard Test Method for Laboratory Evaluation for Wood and Other Cellulosic Materials for Resistance to Termites) [26] was used for termite repellency. Termite repellency is the ability of wood to resist from the attack of termites and prevent these insects from eating the vascular stem of the wood specimen. For the water absorbency test, laboratory test was conducted by referring to the ASTM Standard D 4442-92 (Standard Test Method for Direct Moisture Content Measurement of Wood and Wood-Based Materials) [27]. These test methods cover the determination of the moisture content of solid wood, veneer, and other wood-base materials,

Table 3 The standard method used and frequency of monitoring

\begin{tabular}{llll}
\hline No. & Type of test & ASTM method & Monitoring frequency \\
\hline 1 & Termite Repellency & D-3345-74 & Weekly \\
2 & Water Absorption & D-4442-92 & Weekly \\
3 & Tangential Swelling & D-4446-05 & $30,60,120$ min \\
\hline
\end{tabular}

including those that contain adhesives and chemical additives (Fig. 6). Lastly, ASTM D4446-05 (Standard Test Method for Anti-Swelling Effectiveness of WaterRepellent Formulations and Differential Swelling of Untreated Wood When Exposed to Liquid Water Environments) [28] was used to check the dimensional instability of the coco wood. The tangential swelling or the expansion that happened on the wood sample was measured by comparing the previous dimension (volume) of the sample wood to the measured volume after a period of time being soaked in water (Fig. 7). The standard method and the frequency of analysis are shown in Table 3. The Table 4 shows the initial physical characteristics (i.e., weights and dimension) of coco woods used in three different analyses. Weights monitoring and calculation followed. Employing one tailed T-test, Eqs. (1) to (3) for the evaluation of data and comparing the two means. The computed $t$-values and the critical $t$-values were then compared for validation. IBM SPSS Statistics (2015 version) was used for analyzing statistical data.

$$
\begin{aligned}
& S^{2}=\frac{\sum\left(X_{i}-\bar{X}\right)^{2}}{n-1} \\
& t=\frac{\bar{X}_{1}-\bar{X}_{2}}{\left(\frac{S^{2}}{n_{1}}+\frac{S^{2}}{n_{2}}\right)^{\frac{1}{2}}} \\
& d f=n_{1}+n_{2}-2
\end{aligned}
$$

where: $\mathrm{n}=$ is the number of samples for each setup.

$\mathrm{n}_{1}$ and $\mathrm{n}_{2}$ are the size of sample 1 and 2 , respectively.

$X i=$ is the measured value at $\mathrm{i}$ observation.

$\bar{X}=$ is the mean measurement of the wood samples in each setup.

$\bar{X}_{1}$ and $\bar{X}_{2}$ are the means of sample 1 and 2 , respectively.

$S^{2}=$ is the square of the standard deviations or the variances.

$\mathrm{t}=$ is the computed $\mathrm{t}$ value.

$\mathrm{df}=$ is the degrees of freedom. 


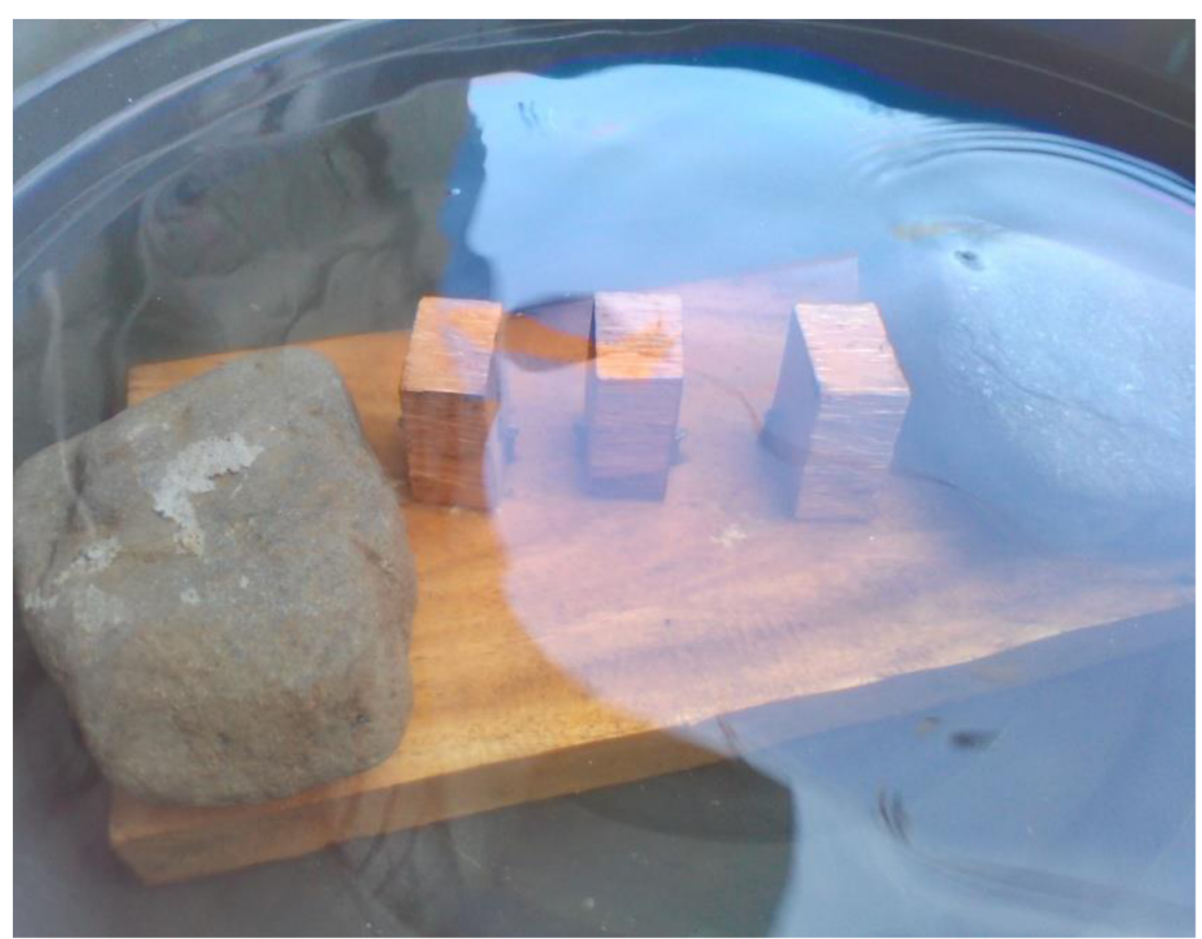

Fig. 6 Water absorbency tes

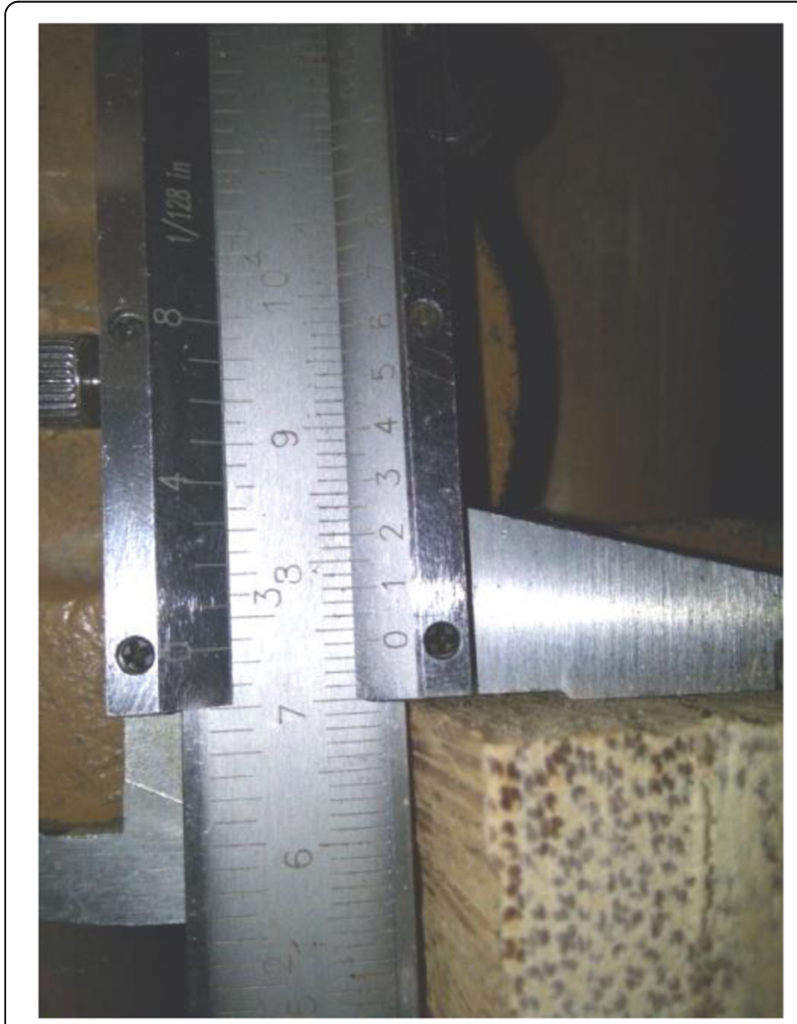

Fig. 7 Tangential swelling test

\section{Results and discussion}

\section{Termite repellency test}

The laboratory test for termite repellency was conducted according to the ASTM D 3345-74 method. If left untreated, coconut wood is prone to termite attack due to its moisture content and soft central tissue. It was shown that the weight was reduced in Sample A (Controlled Sample) by 20, 45, 80 and $100 \%$ during week 1, 2, 3, and 4 respectively. Sample B (with Neem extract from leaves) recorded $0,0,8$ and $28 \%$ weight reduction during the same time frame, while Sample C (with extract from Neem fruits with seed) recorded $0,1,14,32 \%$ weight reduction. This result showed that extract from Neem leaves is slightly more effective as preservative for coco wood compared with extract from fruits with seed. Figure 8 presents the percent decrease in weight of the wood samples due to the devastation of termites. Based on this result, the $50.4 \mathrm{~cm}^{3}$ sample was gone in four weeks, this means that the normal size of coco lumber which is $5 \times 10 \times 365 \mathrm{~cm}\left(18,250 \mathrm{~cm}^{3}\right)$ use in construction of houses and forms without treatment and exposed to termite devastation (without additional environmental factors) can possibly be gone in 1448 weeks. However, additional environmental factors may increase the biodegradation of coco wood and subsequently reduce its shelf life. The 1448 weeks is not equivalent to its shelf life nor its potential use as building material. This aspect requires a separate detailed study. 
Table 4 Initial physical characteristics of coco wood samples, $n=27$

\begin{tabular}{|c|c|c|c|c|c|c|c|c|c|}
\hline \multirow{3}{*}{$\begin{array}{l}\text { Sample } \\
\text { \# }\end{array}$} & \multicolumn{6}{|c|}{ Initial weight (size of $7.6 \times 5.1 \times 1.3 \mathrm{~cm}$ ), g } & \multirow{2}{*}{\multicolumn{3}{|c|}{$\frac{\text { Initial dimension, } \mathrm{cm}}{\text { Tangential swelling test }}$}} \\
\hline & \multicolumn{3}{|c|}{ Termite repellency test } & \multicolumn{3}{|c|}{ Water absorption test } & & & \\
\hline & Sample $[A]$ & Sample [B] & Sample [C] & Sample $[A]$ & Sample [B] & Sample [C] & Sample $[A]$ & Sample [B] & Sample [C] \\
\hline 1 & 28.2 & 29.7 & 29.3 & 28.4 & 31.2 & 32.6 & $7.5 \times 4.4 \times 2.5$ & $7.5 \times 4.5 \times 2.6$ & $7.4 \times 4.4 \times 2.6$ \\
\hline 2 & 27.4 & 30.2 & 30.4 & 27.7 & 32.3 & 33.2 & $7.4 \times 4.4 \times 2.5$ & $7.6 \times 4.5 \times 2.6$ & $7.4 \times 4.4 \times 2.6$ \\
\hline 3 & 26.9 & 28.9 & 30.7 & 27.4 & 33.1 & 32.8 & $7.6 \times 4.5 \times 2.5$ & $7.5 \times 4.4 \times 2.6$ & $7.6 \times 4.5 \times 2.6$ \\
\hline Mean & 27.5 & 29.6 & 30.13 & 27.82 & 32.20 & 32.87 & $7.5 \times 4.4 \times 2.5$ & $7.5 \times 4.5 \times 2.6$ & $7.5 \times 4.4 \times 2.6$ \\
\hline
\end{tabular}

The termite repellency capability has been attributed to the chemical composition of Neem extracts. The GCMS analyses of Hossain et al. [29] work elaborated that Neem crude extracts contained normal hydrocarbons, phenolic compounds, terpeniods, alkaloids, and glycosides. An anti-oxidant capacity evaluation of various extracts was carried out by [29] and found out that chloroform in Neem crude extracts have greater capability than butanol, ethyl acetate extract, hexane extract and methanol extract. It means that the chloroform crude extract from Neem could be used as natural antioxidant [29]. This is attributed to the preservation capability of the Neem extracts in this study.

\section{Water absorption test}

The second analysis was the water absorption. Moisture content is one of the most important variables affecting the mechanical properties of coconut wood. Freshly coconut wood has moisture content approaching saturation throughout the whole stem [30]. It must be processed quickly to avoid deterioration caused by pests and staining. Coconut wood has no natural resistance to wood destroying insects and fungi if exposed to wet weather condition. The samples were investigated on its rate of water absorption. It is observed that Controlled Sample [A] possessed the fastest rate of water absorption. It recorded 4,13, 19\% reduced weight after 30, 60 and $120 \mathrm{~min}$, respectively. While both Samples [B] and [C] showed slower rate of water absorption as shown in Fig. 9. Sample [B] (with extract from Neem leaves) absorbed water by 2,3 , and $6 \%$ after 30,60 and $120 \mathrm{~min}$, respectively. Sample [C] (with extract from Neem fruits with seed) absorbed water by 2, 4, and $7 \%$ after 30, 60, and $120 \mathrm{~min}$, respectively. Again, in this analysis, Sample [B] performed better than Samples [A] and [C]. This result is similar to the result of the studies [31-33] in which Neem extract improved water resistance and dimensional stability of bamboo culms and its products.

\section{Tangential swelling test}

Referring to ASTM Standard D-4446-06, it was used to evaluate the effectiveness of Neem extract for retarding dimensional changes in coated coconut wood submerged in water. Further, it was observed that the Sample [A]

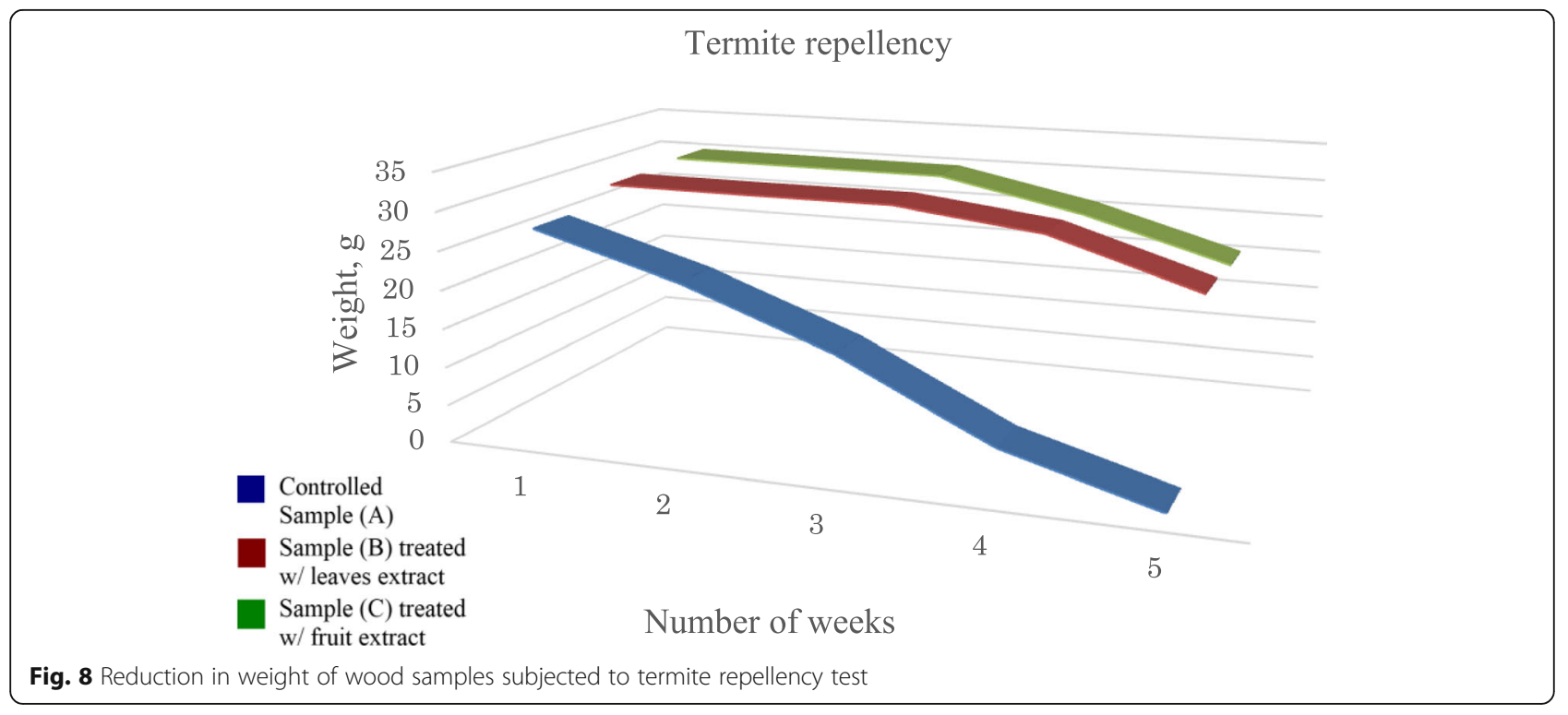




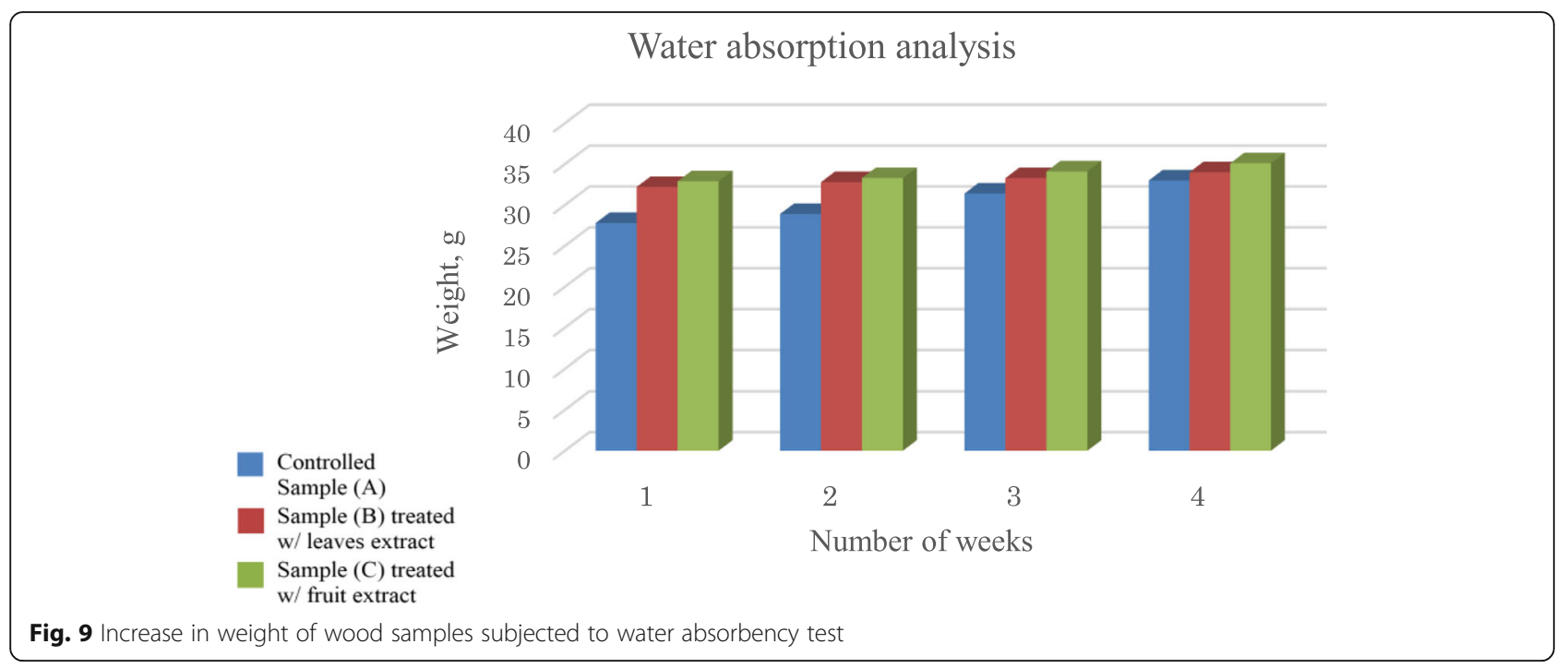

possessed the fastest rate of tangential swelling. It recorded 4, 11, and $16 \%$ after 30,60 and 120 min of soaking in water, respectively. While Samples $[B]$ and $[C]$ showed slower rate of swelling. Sample [B] increased its dimensions by 2, 6, and 10\% after 30, 60 and $120 \mathrm{~min}$, respectively. Sample $[\mathrm{C}]$ increased its dimension by 3, 8 , and $13 \%$ after 30, 60 and $120 \mathrm{~min}$, respectively. Figure 10 presents the increase in volume of the samples due to the swelling of the wood. The percentage increases in volume are based from the means respective to the time interval of observations.

It was observed that there was a direct relation in weights between water absorption and tangential swelling. When the weight of samples in water absorption analysis increased, the weight of samples during tangential swelling results increased as well. A 16 and $14 \%$ increase in the weights and dimensions of Sample [A], respectively, were recorded. This corresponds to 5 and 9\%, as well as 6 and 12\% weights and dimensions of Samples [B] and [C], respectively. This result showed that extract from leaves is more effective in preserving the coco wood against water absorption and tangential swelling. It means that 14$16 \%$ will be the increase of volume of coco wood when exposed to water without Neem extract treatment. This information is important to communities and builders who used untreated coco lumber in areas that have high precipitation and areas with hot climate. Evaporation of water content in coco wood would reduce its weight and dimension. The findings that Neem extract is potential preservative for woods are similar to those findings of various studies in which Neem extract proved its insect repellency and hydrophobic properties [22-25, 34].

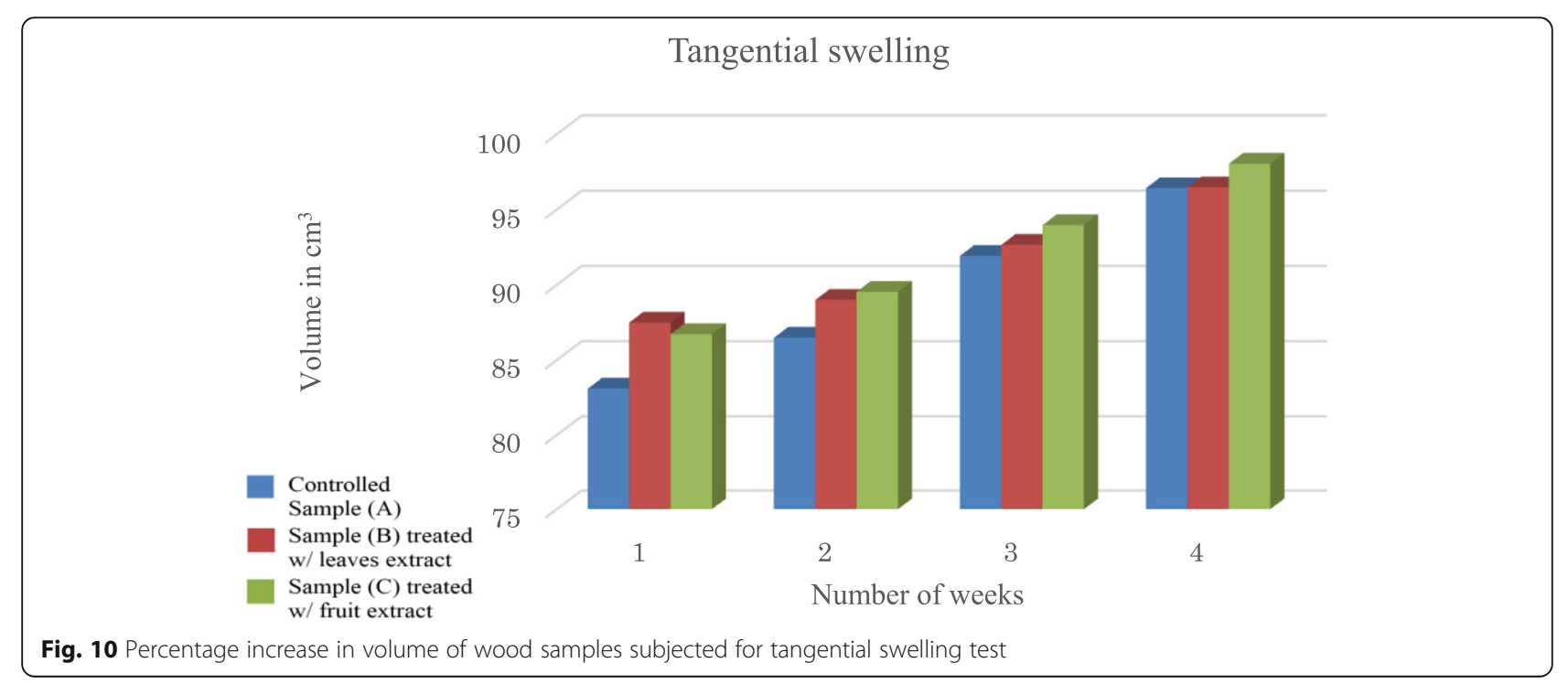




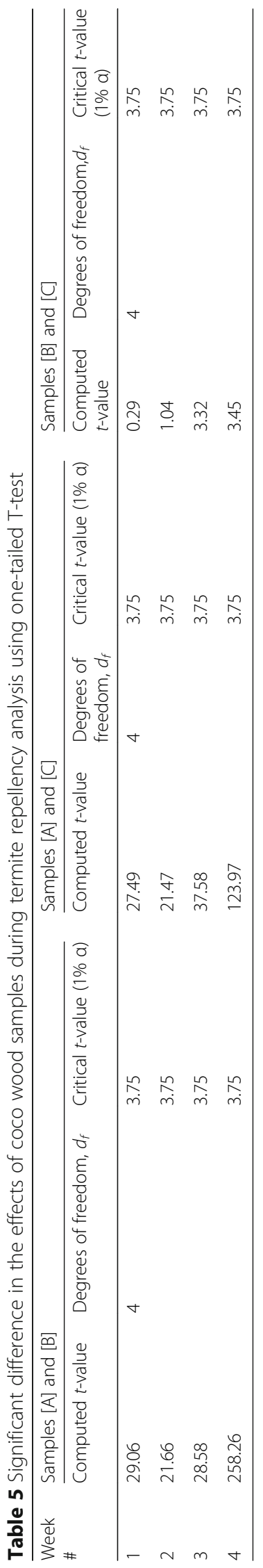




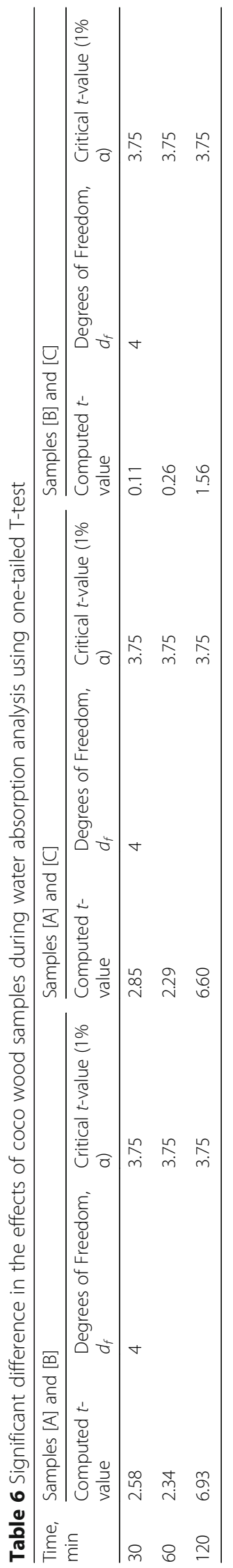




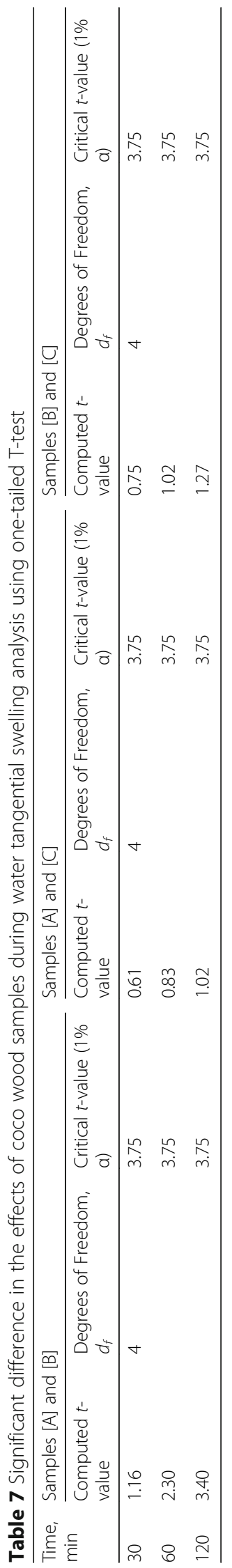




\section{Statistical data analysis}

The data for the termite repellency test, moisture absorption test and tangential swelling test were analyzed by means of computing the percentage changes in weight or volume of wood samples. IBM SPSS Statistics (2015 version) was used for analyzing statistical data.

Tables 5, 6 and 7 depicts the significant differences among three different coco wood samples during termite repellency, water absorption and tangential swelling analysis, respectively. The three tables show the degrees of freedom (df) and the critical values of $t$ at $1 \%$ level of significance respective to the time period of observations. Based on the presented values, in terms of termite repellency, coco wood samples treated with Neem tree extracts (Samples $[\mathrm{A}]$ and $[\mathrm{B}]$ ) showed significant difference compared with Untreated Sample $[\mathrm{C}]$ by recording higher computed $t$ value larger than the critical value of $\mathrm{t}$-value, which is 29.06 and 27.09 respectively on its first week of observation against critical t-value of 3.75 . In terms of water absorption and tangential swelling, only data on water absorption after 120 min both for Samples $[A]$ and $[B]$ showed significantly different values compared with Sample [C] which is 6.93 and 6.60 respectively. The tables also illustrate that computed $t$-value of Sample [B] is lesser than Sample [A]. This means that Sample [A] performs better compared with Sample [B] but not significantly different. In this study, the extracts from leaves recorded same performance with the extracts from combined fruits and seeds. However, this calls for a specific study as to the amount and quality of extracts that the Neem leaves can provide compared with the bark, fruit, and seeds.

\section{Conclusions}

The coco wood samples treated with Neem tree extracts (Samples $[\mathrm{B}]$ and $[\mathrm{C}]$ ) showed significant difference compared with Sample [A] by recording higher computed $\mathrm{t}$ value larger than the critical value of $t$-value. The results reveal that there is no significant difference between extract from leaves (Sample $[\mathrm{B}]$ ) and extract from fruits with seeds (Sample [C]) from all the one tailed T-test conducted (Tables 5, 6 and 7). The result further implies that the effects of deterioration on liquid Neem extract treated wood will yield the same result regardless of which part of the Neem Tree is used. Therefore, Neem extracts, which is a natural resource, is a potential wood preservative especially for termite repellency, protection against water absorption and tangential swelling. This study used simple extraction process with conventional devices, ASTM methods and one-tailed t-test which provided significant evidences that would help identify that Neem tree extract is indeed useful as wood preservatives and could help improve its vulnerability to environmental factors especially from termites and water exposure.

\section{Acknowledgements}

This is to acknowledge the Commission on Higher Education (CHED) of the Republic of the Philippines for supporting the participants of the 2018 International Conference on Sustainable Environmental Technologies (ICSET 2018).

\section{Authors' contributions}

MDC and NFP conceptualized the research study. MDC. performed the measurements, NFP and MMC. were involved in planning and supervised the work, MDC. processed the experimental data, performed the analysis, drafted the manuscript and designed the figures. NFP and MDC. performed the calculations. MDM prepared the samples and tested them. MMC and SDB aided in interpreting the results and worked on the revised manuscript. NFP, MMC and SDB wrote, reviewed and edited the final draft of the Manuscript. All authors discussed the results and commented on the manuscript. All authors read and approved the final manuscript.

\section{Funding}

This research received no external funding.

\section{Availability of data and materials}

All data generated or analyzed during this study is attached as additional supporting file in MS Word format with filename Neem Extract Raw Data.docx.

\section{Competing interests}

The authors declare that they have no competing interests.

\section{Author details}

'Department of Civil Engineering, Marinduque State College, 4900 Boac, Philippines. ${ }^{2}$ School of Civil, Environmental and Geological Engineering, Mapua University, 1002 Manila, Philippines. ${ }^{3}$ School of Agriculture, Fisheries and Natural Sciences, Marinduque State College, 4905 Gasan, Philippines.

Received: 27 January 2019 Accepted: 15 November 2019

Published online: 17 December 2019

References

1. PCA. Yolanda Recovery and Rehabilitation Program. Quezon City: Philippine Coconut Authority; 2018

2. Arancon RNJ. Asia-Pacific forestry sector outlook study: focus on coconut wood. Rome: Food and Agriculture Organization of the United Nations; 1997.

3. DEEDI. Cocowood: properties and processing facts for coconut wood. Brisbane: Department of Employment, Economic Development and Innovation; 2010.

4. Mohan D, Shi J, Nicholas DD, Pittman CU, Steele PH, Cooper JE. Fungicidal values of bio-oils and their lignin-rich fractions obtained from wood/bark fast pyrolysis. Chemosphere. 2008;71:456-65.

5. Temiz A, Alma MH, Terziev N, Palanti S, Feci E. Efficiency of bio-oil against wood destroying organisms. J Biobased Mater Bio. 2010;4:317-23 I have no idea why you changed my line to the wrong one. It should be longer.

6. Deacon JW. Fungal biology. 4th ed. Malden: Blackwell Publishing Ltd; 2006.

7. Baronas R, Ivanauskas F, Juodeikiene L, Kajalavicius A. Modelling of moisture movement in wood during outdoor storage. Nonlin Anal Model Contr. 2001;6:3-14

8. Khazaei J. Water absorption characteristics of three wood varieties. Agronomical Res Moldavia. 2008;41:5-16.

9. Morris PI, Winandy JE. Limiting conditions for decay in wood systems. In: 33rd Annual Meeting of the International Research Group on Wood Preservation. Cardiff; 2002 May 12-17.

10. Winandy JE, Curling SF, Lebow PK. Controlling moisture content of wood samples using a modified soil-pan decay method. Forest Prod J. 2005;55:80-5.

11. Acda MN. Evaluation of lahar barrier to protect wood structures from Philippine subterranean termites. Philipp J Sci. 2013;142:21-5.

12. Rust MK, Su NY. Managing social insects of urban importance. Annu Rev Entomol. 2012;57:355-75.

13. Su NY, Hsu EL. Managing subterranean termite populations for protection of the historic Tzu-Su temple of san-Shia, Taiwan (Isoptera: Rhinotermitidae). Sociobiology. 2003;41:529-45. 
14. Yudin L. Termites of Mariana islands and Philippines, their damage and control. Sociobiology. 2002;40:71-4.

15. Hedges S. Termite inspections. Pest Control Tech. 1992;20:30-3.

16. Baselt RC. Disposition of toxic drugs and chemicals in man. 8th ed. Foster City: Biomedical Publications; 2008.

17. Bloomfield F. Propiconazole - toxicity, side effects, diseases and environmental impacts. Pesticides.News; 2017.

18. HH. Solignum wood preservative. Singapore: Horme Hardware. https:// www.horme.com.sg/product.aspx?id=2427. Accessed 7 Jul 2018.

19. Amazon. Barrettine premier wood preservative. https://www.amazon.com/ Barrettine-Premier-Wood-Preservative_wood+preservative. Accessed 7 Jul 2018.

20. National Research Council. Neem: a tree for solving global problem. Washington, DC: National Academy Press; 1992.

21. Lee JW, Jin CL, Jang KC, Choi GH, Lee HD, Kim JH. Investigation on the insecticidal limonoid content of commercial biopesticides and neem extract using solid phase extraction. J Agri Chem Env. 2013;2:81-5.

22. Mordue AJ, Nisbet AJ. Azadirachtin from the neem tree Azadirachta indica: its action against insects. An Soc Entomol Bras. 2000;29:615-32.

23. Dash SP, Dixit S, Sahoo S. Phytochemical and biochemical characterizations from leaf extracts from Azadirachta Indica: an important medicinal plant. Biochem Anal Biochem. 2017;6:323.

24. Djibril D, Mamadou F, Gerard V, Geuye MDC, Oumar S, Luc R. Physical characteristics, chemical composition and distribution of constituents of the Neem seeds (Azadirachta indica a. Juss) collected in Senegal. Res J Chem Sci. 2015;5:52-8.

25. El-Hawary SS, El-Tantawy ME, Rabeh MA, Badr WK. Chemical composition and biological activities of essential oils of Azadirachta indica a. Juss. Int J Appl Res Nat Prod. 2013;6:33-42.

26. ASTM. Standard test method for laboratory evaluation for wood and other cellulosic materials for resistance to termite (D3345-74). West Conshohocken: American Society for Testing and Materials International; 1999.

27. ASTM. Standard test methods for direct moisture content measurement of wood and wood-based materials (D4442-92). West Conshohocken: American Society for Testing and Materials International; 2003.

28. ASTM. Standard test method for anti-swelling effectiveness of waterrepellent formulations and differential swelling of untreated wood when exposed to liquid water environments (D4446-05). West Conshohocken: American Society for Testing and Materials International; 2005.

29. Hossain MA, Al-Toubi WAS, Weli AM, Al-Riyami QA, Al-Sabahi JN. Identification and characterization of chemical compounds in different crude extracts from leaves of Omani neem. J Taibah Univ Sci. 2013;7:181-8.

30. Findlay GW, editor. Preservation of timber in the tropics. Dordrecht: Springer; 1985.

31. Erakhrumen AA, Ogunsanwo OY. Water absorption, anti-swell efficiency, and dimensional stability properties of neem seed-oil treated wild grown Bambusa vulgaris Schrad ex J.C. Wendl. in southwest Nigeria. BioResources. 2009:4:1417-29.

32. Sarawaneeyaruk S, Krajangsang S, Pringsulaka O. The effects of neem extract and azadirachtin on soil microorganisms. J Soil Sci Plant Nutr. 2015;15:1071-83.

33. Acharya P, Mir SA, Nayak B. Competence of biopesticide and neem in agriculture. Int J Env Agr Biotech. 2017;2:2958-64.

34. Addisu S, Mohamed D, Waktole S. Efficacy of botanical extracts against termites, Macrotermes spp., (Isoptera: Termitidae) under laboratory conditions. Int J Agric Res. 2014;9:60-73.

\section{Publisher's Note}

Springer Nature remains neutral with regard to jurisdictional claims in published maps and institutional affiliations.

Ready to submit your research? Choose BMC and benefit from:
- fast, convenient online submission
- thorough peer review by experienced researchers in your field
- rapid publication on acceptance
- support for research data, including large and complex data types
- gold Open Access which fosters wider collaboration and increased citations
- maximum visibility for your research: over 100M website views per year
At BMC, research is always in progress.
Learn more biomedcentral.com/submissions

